\title{
High rates of incarceration due to drug trafficking in the last decade in southern Brazil
}

\author{
Felipe Ornell, ${ }^{1,2}$ (D) Bárbara S. Stock, ${ }^{3,4}$ Juliana N. Scherer,${ }^{1,2}$ Rafaela Ornell, ${ }^{1}$ Karina P. Ligabue,,${ }^{1,2}$ \\ Joana C. M. Narvaez,${ }^{1,5}$ Carla Dalbosco,${ }^{1}$ Renata M. Dotta ${ }^{6}$ Lisieux B. Telles ${ }^{1}$ Flavio Pechansky,${ }^{1,2}$ \\ Lisia von Diemen, ${ }^{1,2}$ Felix H. P. Kessler ${ }^{1,2}$
}

\begin{abstract}
Introduction: Drug-related crimes, especially drug trafficking, account for a large part of incarcerations not only in Brazil, but also worldwide. It is not clear whether the change in the drug law has contributed to the increase in the number of drug trafficking prisoners. Few studies have investigated gender differences and the growth of drug trafficking offenses in the Brazilian southern state of Rio Grande do Sul.

Objective: To investigate the growth of the prison population in the state of Rio Grande do Sul, emphasizing incarcerations for drug trafficking and gender differences.

Method: This was an ecological study using secondary data collected from official databases of the Brazilian National Penitentiary Department (Departamento Penitenciário [DEPEN]), affiliated with the Brazilian Ministry of Justice.

Results: Between 2006 and 2015, incarcerations increased by 27\% (25\% men, 83\% women). Incarcerations for drug trafficking accounted for $11 \%$ of total arrests in 2006 ( $11 \%$ men, $20 \%$ women) and $45 \%$ in 2015 ( $47 \%$ men, $91 \%$ women), corresponding to an increase of $427 \%$ ( $415 \%$ among men, $723 \%$ among women).

Conclusions: Imprisonment for drug trafficking has increased considerably, especially among women. This may be due to factors such as: increase of drug trafficking, increase in the numbers of gangs in the state, and changes in the Brazilian drug law. These results highlight an emerging challenge in public health from the perspective of human rights and gender.
\end{abstract}

Keywords: Public health, prison, drug trafficking, women.

\section{Introduction}

Increases in prison population sizes are a worldwide observed phenomenon. ${ }^{1}$ Brazil has high rates of incarceration, surpassed only by the United States, China and Russia. However, when prisoners under house arrest are included, Brazil has the third largest prison population of the world. Between 2003 and 2014 , the prison population size grew by $86 \%$ in the country: from 302,495 to 563,526 inmates, exceeding the number of slots. ${ }^{2}$ Currently, the incarceration rate in Brazil is higher than the rate of inmates leaving

\footnotetext{
${ }^{1}$ Centro de Pesquisa em Álcool e Drogas, Centro Colaborador em Álcool e Drogas, Hospital de Clínicas de Porto Alegre (HCPA), Universidade Federal do Rio Grande do Sul (UFRGS), Porto Alegre, RS, Brazil. ${ }^{2}$ Programa de Pós-Graduação em Psiquiatria e Ciências do Comportamento, UFRGS, Porto Alegre, RS, Brazil. ${ }^{3}$ Facultad de Ciencias Jurídicas, Económicas y Administrativas, Universidad Católica de Temuco, Temuco, AR, Chile. ${ }^{4}$ Núcleo de Pesquisa em Direito Penal e Criminologia, UFRGS, Porto Alegre, RS, Brazil. ${ }^{5}$ Universidade Federal de Ciências da Saúde de Porto Alegre, Porto Alegre, RS, Brazil. ${ }^{6}$ Fundação Escola Superior do Ministério Público (FMP), Porto Alegre, RS, Brazil.

Submitted Jul 09 2019, accepted for publication Nov 042019.

Suggested citation: Ornell F, Stock BS, Scherer JN, Ornell R, Ligabue KP, Narvaez JCM, et al. High rates of incarceration due to drug trafficking in the last decade in southern Brazil. Trends Psychiatry Psychother. 2020;42(2):153-160. http://dx.doi.org/10.1590/2237-6089-2019-0061
} 
prison, which increases the chance of inmate exposure to unhealthy conditions such as overcrowding, poor bedding, ventilation, and hygiene conditions. These factors, in turn, make inmates especially vulnerable to the development of mental and physical health problems, such as infectious diseases (e.g., HIV, tuberculosis, syphilis, hepatitis $\mathrm{B}$ and $\mathrm{C}$ ), and also contribute to the loop of increased criminality and lower rehabilitation in the system. . $^{3,4}$

Drug-related crimes, especially drug trafficking, account for a large part of incarcerations not only in Brazil, but also worldwide. ${ }^{3}$ For this reason, in 2006 the Brazilian government created the National System of Public Policies on Drugs (Sistema Nacional de Políticas Públicas sobre Drogas [SISNAD]), which modified public policies by, for example, punishing drug possession without deprivation of liberty - but not decriminalizing it. ${ }^{5,6}$ This law also extinguished detention for those who are caught with drug possession for their own use, proposing alternative penalties that range from verbal warnings to the provision of community service. However, no objective criteria are available to determine whether a drug is intended for sale or consumption. Thus, even though only those considered drug dealers should be incarcerated, the decision on who should be considered a drug dealer is left to the police authority who made the arrest. While the Brazilian public ministry and the judiciary are responsible for interpreting that decision, this may happen a long time after the incarceration. ${ }^{6}$

In fact, international studies reveal a growth in the number of drug offenses committed by women, particularly drug trafficking, raising concerns about the causes and consequences of female involvement in drug-related crimes. ${ }^{7}$ Even with a significant increase in the number of incarcerated women in Brazil, few studies have investigated gender differences and the growth of drug trafficking offenses in Rio Grande do Sul, the state with one of the highest rates of illicit drug use in our country.

Changes in the drug law, the increase in the inmate population and the change in the profile of prisoners all have an impact on the work of health professionals who assist this population. These issues need to be considered during the development of collaborative, effective and humanized health practices. ${ }^{8}$ Therefore, this study aimed to analyze the growth in the inmate population in the state of Rio Grande do Sul during the last 10 years (from 2006 to 2015), emphasizing the incidence of drug-related incarcerations and gender differences.

\section{Methods}

This was an ecological study that evaluated data on the inmate population of the state of Rio Grande do Sul, from 2006 to 2015 . This timeframe comprises the period after the enactment of Law 11343/2006, which instituted the SISNAD, thus redirecting state action towards drug users and dependents and intensifying repression of illicit drug production and trafficking. Data regarding the years 2016-2019 are still unavailable.

Information about the period between 2006 and 2012 was obtained from the statistical-analytical reports of the prison system of Rio Grande do Sul, provided and maintained by the Brazilian National Penitentiary Department (Departamento Penitenciário [DEPEN]), affiliated with the Brazilian Ministry of Justice. ${ }^{9}$ This is the official database of the Brazilian prison system, and data become available in annual reports issued by the state's Superintendence of Penitentiary Services (Superintendência dos Serviços Penitenciários [SUSEPE]). The system was created in 2006, and therefore data on the period before 2006 are not available. Information about the period between 2013 and 2015 (latest reports) was provided by SUSEPE, as these reports were not available online. ${ }^{10}$

Data on the estimate of the Rio Grande do Sul population was obtained from the homepage of the state's official economics and statistics organization (Fundação de Economia e Estatística Siegfried Emanuel Heuse). ${ }^{11}$ Indicators are presented in absolute numbers and per 100,000 inhabitants.

All data were downloaded from the original source websites and extracted by a trained researcher (FO) following a pre-established protocol using a Google form. The protocol included the following information, always focusing on the state of Rio Grande do Sul only: total population per year; total number of prisoners per year; number of men imprisoned per year; number of women imprisoned per year; imprisonment for drug trafficking per year; imprisonment for drug trafficking among men per year; imprisonment for drug trafficking among women per year. The data collected were automatically entered into Microsoft Excel $^{\circledR}$ (Microsoft Office 2013), and the statistical analysis was also performed using Excel ${ }^{\circledR}$. Data were analyzed on January 10, 2018. From the data collected, we calculated the percentage of prisoners per 100,000 inhabitants per year (= total cases) population $\times 100,000$ ) in all categories (total prisoners, total prisoners for trafficking, men and women). Afterwards, the percentage of incarcerations for 
drug trafficking and international traffic of narcotics, which was already stratified by gender, was extracted. Because no individual information was available in the databases, it was not possible to perform individual statistics such as correlations.

This study used secondary data collected in public and official data banks, and therefore review and approval by an ethics committee was not necessary.

\section{Results}

Our results showed a significant increase in the number of incarcerations in the state of Rio Grande do Sul during the last decade. In 2006, the overall incarceration rate was $221 / 100,000$ inhabitants/ year, having increased by $27 \%$ in 2015 (281/100,000 inhabitants/year). Male incarcerations increased by $25 \%$ (435 to $545 / 100,000$ inhabitants/year), whereas female incarcerations increased by $83 \%$ (16 to $30 / 100,000$ inhabitants/year) (Table 1).

Considering imprisonment for drug trafficking, there was an overall increment of $427 \%$ ( 23 to $126 / 100,000$ inhabitants/year), with a growth of $415 \%$ (44 to 229/100,000 inhabitants/year) among men (Figure 1) and $723 \%$ ( 3 to $28 / 100,000$ inhabitants/year) among women (Figure 2).

Incarcerations for drug trafficking accounted for 11 and $45 \%$ of all arrests in 2006 and 2015, respectively, with corresponding increases from 11 to $47 \%$ among men and from 20 to $91 \%$ among women. These data are shown in Figure 3.

Table 1 - Rates of total incarcerations and incarcerations for drug trafficking among men and women in the state of Rio Grande do Sul, Brazil

\begin{tabular}{|c|c|c|c|c|c|c|c|c|c|c|}
\hline & 2006 & 2007 & 2008 & 2009 & 2010 & 2011 & 2012 & 2013 & 2014 & 2015 \\
\hline Total of prisoners & 23,814 & 25,602 & 27,636 & 28,750 & 31,383 & 29,113 & 29,243 & 28,198 & 29,284 & 31,573 \\
\hline $\begin{array}{l}\text { Incarcerations per } 100,000 \\
\text { inhabitants }\end{array}$ & 221 & 236 & 253 & 262 & 285 & 263 & 263 & 253 & 261 & 281 \\
\hline Total incarcerations, men & 22,906 & 24,456 & 26,341 & 27,012 & 29,298 & 27,102 & 27,341 & 26,427 & 27,573 & 29,829 \\
\hline $\begin{array}{l}\text { Incarcerations per } 100,000 \\
\text { inhabitants, men }\end{array}$ & 435 & 462 & 495 & 505 & 546 & 503 & 505 & 486 & 506 & 545 \\
\hline Total incarcerations, women & 908 & 1,146 & 1,295 & 1,738 & 2,085 & 2,011 & 1,902 & 1,771 & 1,711 & 1,744 \\
\hline $\begin{array}{l}\text { Incarcerations per } 100,000 \\
\text { inhabitants, women }\end{array}$ & 16 & 21 & 23 & 31 & 37 & 35 & 33 & 31 & 30 & 30 \\
\hline Imprisonment for drug trafficking & 2,524 & 1,627 & 3,599 & 5,229 & 8,952 & 9,578 & 9,861 & 12,978 & 13,303 & 14,126 \\
\hline $\begin{array}{l}\text { Imprisonment for drug trafficking per } \\
100,000 \text { inhabitants }\end{array}$ & 23 & 15 & 33 & 48 & 81 & 87 & 89 & 116 & 119 & 126 \\
\hline $\begin{array}{l}\text { Imprisonment for drug trafficking } \\
\text { among men }\end{array}$ & 2,340 & 1,412 & 3,047 & 4,355 & 7,517 & 8,008 & 8,408 & 11,385 & 11,759 & 12,538 \\
\hline $\begin{array}{l}\text { Imprisonment for drug trafficking per } \\
100,000 \text { inhabitants among men }\end{array}$ & 44 & 27 & 57 & 81 & 140 & 149 & 155 & 209 & 216 & 229 \\
\hline $\begin{array}{l}\text { Imprisonment for drug trafficking } \\
\text { among women }\end{array}$ & 184 & 215 & 552 & 874 & 1,435 & 1,570 & 1,453 & 1,593 & 1,544 & 1,588 \\
\hline $\begin{array}{l}\text { Imprisonment for drug trafficking per } \\
100,000 \text { inhabitants among women }\end{array}$ & 3 & 4 & 10 & 16 & 25 & 28 & 25 & 28 & 27 & 28 \\
\hline
\end{tabular}

Source: Brazilian National Penitentiary Department (Departamento Penitenciário [DEPEN]), Brazilian Ministry of Justice. 


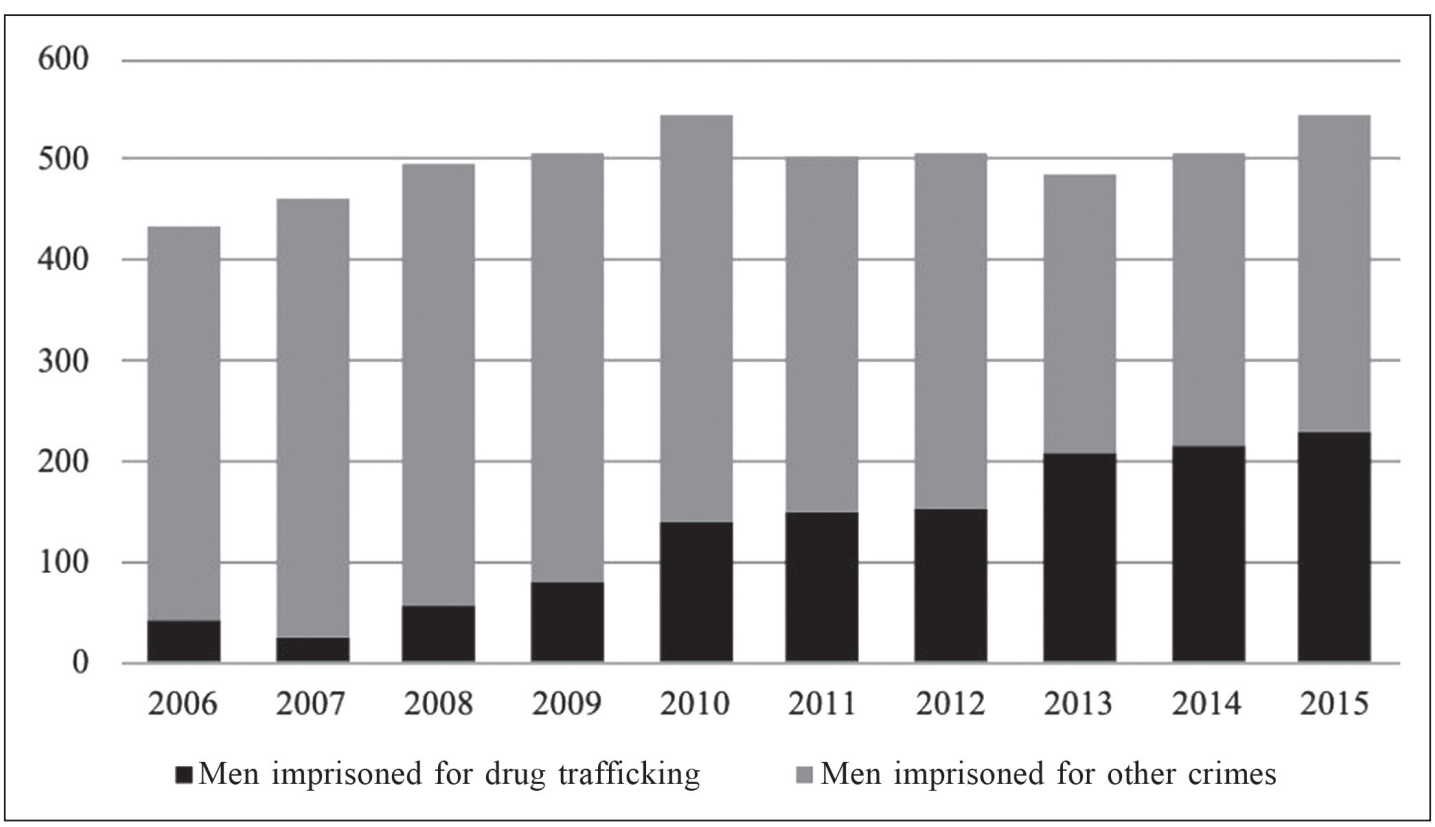

Figure 1 - Percentage of men incarcerated for drug trafficking or other crimes per 100,000 inhabitants in Rio Grande do Sul, Brazil (2006-2015). Source: Brazilian National Penitentiary Department (Departamento Penitenciário [DEPEN]), Brazilian Ministry of Justice.

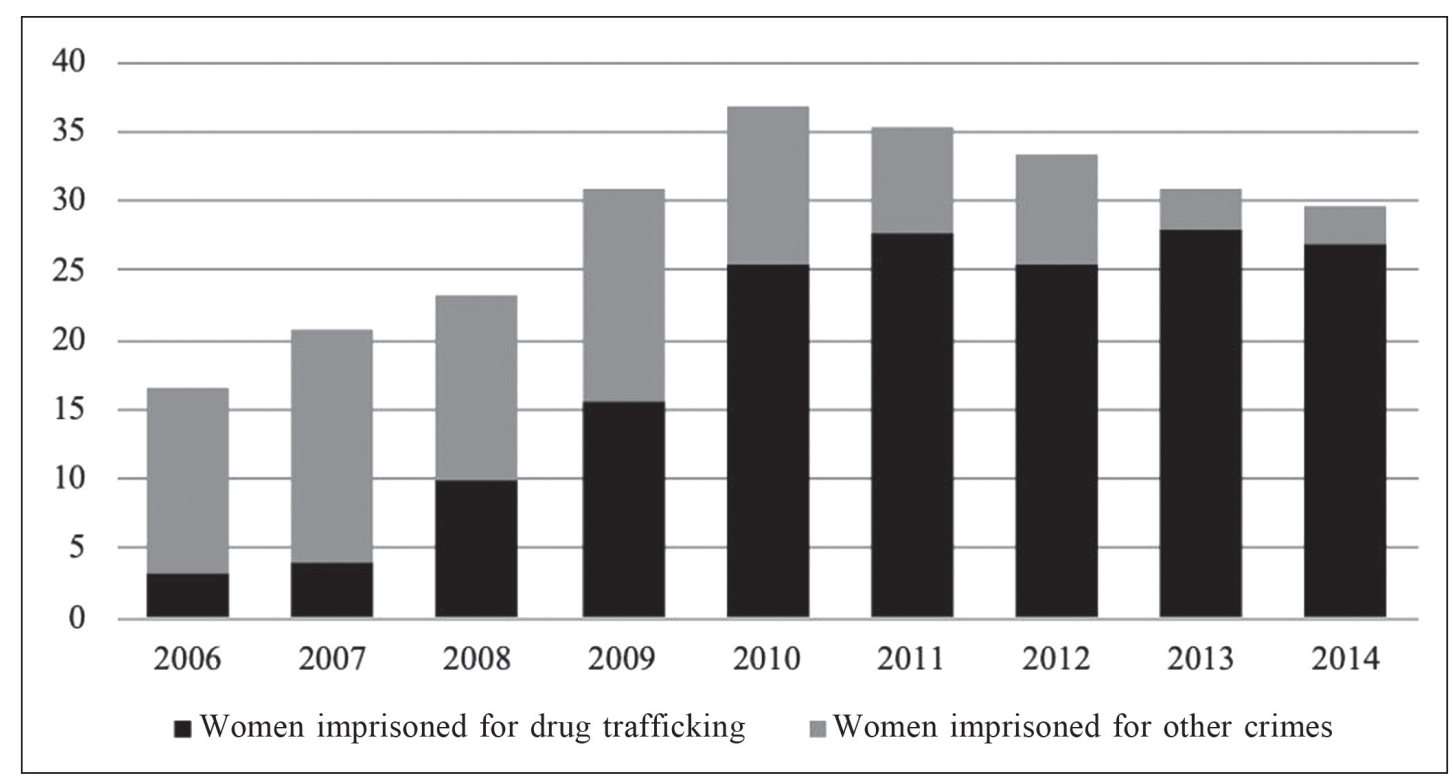

Figure 2 - Percentage of women incarcerated for drug trafficking or other crimes per 100,000 inhabitants in Rio Grande do Sul, Brazil (2006-2015). Source: Brazilian National Penitentiary Department (Departamento Penitenciário [DEPEN]), Brazilian Ministry of Justice. 


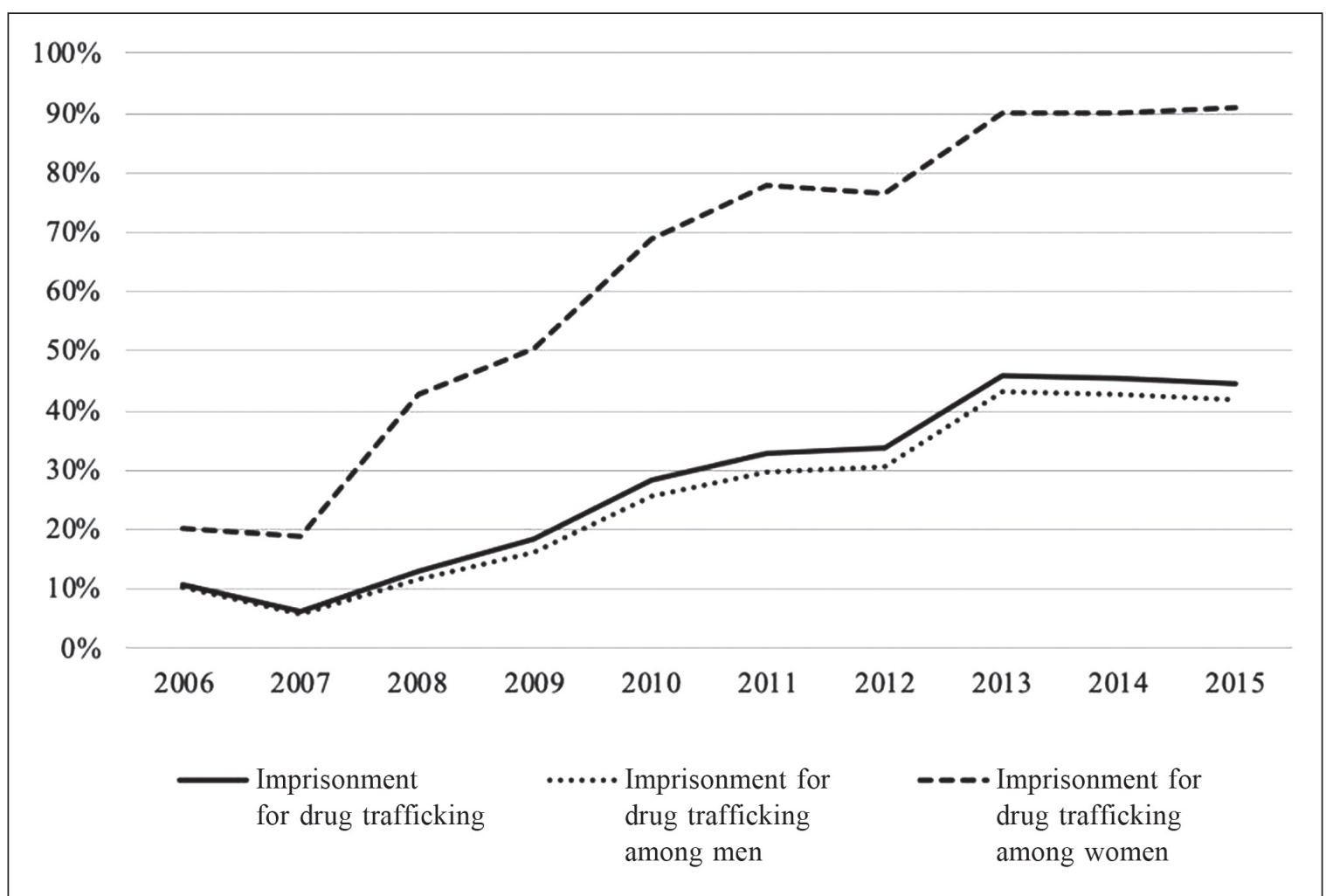

Figure 3 - Increase in the percentage of women arrested for drug trafficking compared to men and total imprisonments (2006-2015). Source: Brazilian National Penitentiary Department (Departamento Penitenciário [DEPEN]), Brazilian Ministry of Justice.

\section{Discussion}

This study reports the increase in drug-related imprisonment rates in the state of Rio Grande do Sul, Brazil, and the alarming growth in drug-related incarcerations among women in the period from 2006 to 2015. Of particular interest is the fact that the increase in incarcerations for drug-trafficking in Rio Grande do Sul in this period was 14 times higher than the increase in the number of incarcerations for other types of crimes. These results are in line with international evidence suggesting that drug trafficking is one of the leading causes of incarceration worldwide, and that there has been a large increase in female incarceration due to drug-related crimes in the last decade. ${ }^{8,12}$

The Brazilian judicial system has historically been based strictly on punitive strategies, focusing primarily on the fulfillment of punishment, with poor articulation with health and social networks. ${ }^{12}$ In this sense, Law 11343/2006 brought important improvements, e.g., by avoiding incarceration for drug possession, acknowledging drug addiction as a public health problem, and proposing treatments to be performed by health services. Conversely, the stronger repression to drug trafficking, with an increase in the minimum sanction to 5 years of imprisonment, could be contributing to the growth of incarceration rates. Nation-wide studies conducted in Brazil show that legislative changes did not exert significant impact on reducing drug trafficking, due to their focus remaining on the retail trade and the most vulnerable segments of the illicit drug trade. ${ }^{5}$ Also, subjective aspects of the law could lead to the imprisonment of users framed as drug dealers, since the law does not specify criteria for differentiation between the two categories. ${ }^{6}$ In this sense, the Brazilian law failed to distinguish users carrying drugs from drug dealers and refer consumers to the health care system; rather, it has resulted in the intensification of incarceration. In addition, due to the unclear criteria of the law in relation to the distinction between users and traffickers, the repression derived from its enforcement is selective, mainly affecting the poorest population, in addition to reinforcing the vulnerability associated with gender issues in the country.

In addition to the legal aspects, other factors such as the emergence and strengthening of criminal gangs 
in the last decades in Brazil seem to have contributed to the increase of drug-related crimes. These organizations, which at first emerged as horizontal networks of mutual protection to demand better conditions in prison settings, now have an important and strong role in the drug trafficking market. ${ }^{13-15}$ The establishment of criminal gangs in the state of Rio Grande do Sul, which started to develop in 1987 and are present until today, should also be taken into consideration when interpreting the data. The organization of gangs through prisons contributed to the expansion of drug trafficking and the establishment of gangs in specific geographic regions. In this sense, while in 2003 there were only three acknowledged gangs present in the Central Prison of Porto Alegre (the largest state prison, located in the capital), currently there are at least eight. It should be noted that new gangs emerging after 2005 exhibit peculiar characteristics, namely high firepower and perversity in their actions. ${ }^{13-15}$

Regarding the analysis by gender, our results showed that the number of male incarcerations increased significantly in the period, but still below the increase observed in female incarcerations. Our findings corroborate previous data indicating that female violence rates in recent years are higher than those reported for males. However, the rates found in the present study are higher than those previously reported. ${ }^{3}$ Although female prisoners account for only $5.52 \%$ of the whole inmate population of Rio Grande do Sul, it is clear that the percentage growth between 2006 and 2015 among women was way above the one observed among men, with drug trafficking being the cause of imprisonment in $90 \%$ of women arrested in 2015 . We cannot rule out that this increase may be related to the rise in the consumption of illicit drugs by women, since there is lack of systematic data concerning drug use in this population.

Recent studies have found that partners involved in criminal activities greatly influence women to commit transgressions. ${ }^{16}$ In a context of low economic growth, many people find a way to keep living by working for drug and crime organizations - including women and children, who can earn a good amount of money in a short time with no qualification at all. Women are usually involved in inferior activities in the drug trafficking hierarchy, e.g., packing drugs, hiding drugs in their houses and carrying small amounts. The type of work that women carry out suggests that drug trafficking has gender-specific activities. ${ }^{17}$ In this sense, some authors suggest that the increase in incarcerations of women for drug trafficking is linked to their higher involvement in subordinate functions in the hierarchical scale of trafficking, acting as drug mules, "accomplices," or negotiators of small amounts of drugs, which facilitate criminal activities. ${ }^{3}$ Because women perform tasks considered to be secondary in trafficking, their imprisonment usually does not disrupt the drug trafficking network. ${ }^{7}$

The increased involvement of women in the drug market may also be attributed to other sociodemographic variables such as low wages, unemployment and increase of female-headed households. ${ }^{18}$ Previous studies suggest that, in such contexts, drug dealing becomes an ease way to obtain money, power and authority, in addition to non-submission to social rules. ${ }^{19}$ Therefore, the economic crisis observed in Brazil in the last decade could also be contributing to the increased number of women involved in drug-related crimes.

A previous investigation conducted with female prisoners in the state of Rio Grande do Sul showed that this is a socially vulnerable population. Many of the assessed women reported having suffered physical and sexual abuse on several occasions. ${ }^{4}$ The rates of drug abuse/addiction and withdrawal symptoms in prison were also high. Moreover, many women reported being under the effect of drugs at the time of the offense, and several were arrested while trafficking into prison for comrades or family members. ${ }^{20}$ A previous study has shown that female prisoners are a population with serious mental health problems, whose involvement with drugs is not limited to trafficking. ${ }^{21}$ This is in line with previous studies conducted in the general Brazilian population that showed that licit and illicit drug use has increased among women. ${ }^{22-24}$ Even though there are no studies showing exact numbers of drug users receiving treatment in Brazil, it is known that most patients enrolled in Centers for Psychosocial Care for Alcohol and Drug Treatment (Centro de Atenção Psicossocial Álcool e Drogas [CAPS AD]) are men. ${ }^{24,25}$ The present findings suggest the need for an articulation between the judicial and health systems. Finally, evidence suggests that prison health care usually does not offer or is not prepared to offer drug use treatment for women. ${ }^{26}$

In this sense, the deliberations issued by the United Nations Office on Drugs and Crime in 2016, following the release of the United Nations World Drug Report, ${ }^{12}$ point to the development of policies that acknowledge the important differences between men and women, especially with regard to standards of use and vulnerability. In all 17 sustainable development goals set forth, ${ }^{27}$ the United Nations contemplates gender equality, i.e., the need to achieve gender equality and empower all women, especially those with psychiatric disorders comorbid with drug use. These women usually face several barriers in the criminal justice system, and health systems are generally not adequately equipped 
to meet their specificities. ${ }^{12}$ Furthermore, it has been observed that treatment programs for substance use disorders are predominantly designed with a focus on men, disregarding gender issues. This aspect has lately been brought under discussion, since female prisoners exhibit a profile of drug use ${ }^{28}$ and involvement with transgressive activities distinct from that observed in men, thus indicating that the treatment needs of women and men are also different, and that the options currently available are inappropriate for the treatment of women. ${ }^{16}$

There have been major advances in relation to human rights and access to health care in Brazil, especially in relation to vulnerable and marginalized populations such as drug users, including those incarcerated and especially women. In Brazil, and particularly in the southern state of Rio Grande do Sul, actions and health services in prisons have been shifting from management focused on public safety to management focused on health care. Efforts have been made to ensure that the population deprived of liberty has access to the Brazilian Unified Health System (Sistema Único de Saúde [SUS]), to establish basic health units within prison premises and to developed ongoing training activities. This approach was particularly encouraged by two national policies, one dedicated to ensure health care to all prisoners in general and another focusing specifically on women's needs, both during and after imprisonment. The first of these policies was inspired by the experience of the department of health of the state of Rio Grande do Sul. ${ }^{8}$ However, the work of health professionals in these settings faces a series of challenges, especially considering the increase in prison population and the need to take gender issues into account. In this sense, the increase in prison population is worrying, since it worsens indicators of physical and mental insalubrity, ${ }^{3,4}$ due to the poor living conditions to which prisoners are exposed - especially women, given the expressive increase in their incarceration and the lack of investment in physical accommodation. Also, the increase in prison population, contrasting with the few health resources available, make it unfeasible to offer health care to the incarcerated population.

It is important to consider the limitations of the present study. First, data were obtained from public information systems, and therefore the processes of data collection and input to the databases are not described in detail, and are prone to several types of bias. Second, this was an ecological study: due to the lack of individual data, it was not possible to perform statistical analysis of the relationship between individual variables such as sociodemographic data and violence-related information. We chose to employ these data due to the non-existence of other representative epidemiological data, and also due to the fact that these are the official data used in Brazil. Third, the databases assessed lack some important information, such as co-occurrence with other crimes, presence of psychiatric disorders (mainly addiction), among others. Therefore, we could not delineate the profile of women who are being incarcerated due to drug trafficking. It would be important for further studies to address these aspects, along with proposals for treatment and recovery programs and/or interventions for incarcerated women.

\section{Conclusions}

Our results showed an increase in incarceration rates in the Brazilian southern state of Rio Grande do Sul during the last decade, especially due to drug trafficking offenses. This may be due to two factors: the increase in the number of trafficking and criminal gangs in the state observed after 2005; and the changes in the law that implemented the SISNAD and proposed distinct sanctions for users and traffickers. It is important to consider the high rates of women among inmates arrested for drug-related offenses, including non-sentenced and provisional prisoners. These data point out the importance of this topic as an emerging issue in the fields of public health, human rights and public security, as well as the need for gender-specific health and public policies. Understanding the profile of the prisoners, their motivation for getting involved in crime, and their clinical and social assistance needs is, therefore, essential to the development of such policies. In addition, the authors suggest that new actions should be intersectoral, focusing on essential rights (including health and socioeconomic equality) and on gender specificities.

\section{References}

1. Walmsley R. World prison population list. London: International Centre for Prison Studies; 2016.

2. Brasil, Conselho Nacional de Justiça. Novo diagnóstico de pessoas presas no Brasil. Brasília: CNJ; 2014.

3. Souza KOJ. A pouca visibilidade da mulher brasileira no tráfico de drogas. Psicol Estud. 2009;14:649-57.

4. Stock BS, Panichi RMD, Fuzinatto AM. ¿Privarlas de libertad es privarlas de salud? Interlocuciones entre género, salud pública y prisión a partir de la experiencia de un equipo de atención básica. Pap Rev Sociol. 2017;102:337.

5. Boiteux L, Castilho EWV de, Vargas B, Batista VO, Prado GLM. Projeto Pensando o Direito: tráfico de drogas e Constituição. Rio de Janeiro/Brasília: UNB/FND/UFRJ; 2009.

6. Brasil. Lei no 11.343, de 23 de agosto de 2006 [Internet]. 2006 [cited 2018 Feb 23]. http://www.planalto.gov.br/ccivil_03/_ ato2004-2006/2006/lei/l11343.htm 
7. Walmsley R. World prison brief. World female imprisonment list. Women and girls in penal institutions, including pre-trial detainees/remand prisoners. 4th ed. London: Birkbeck University of London; 2015.

8. Ornell F, Dotta RM, Scherer JN, Modena SL, Dal Cin V, Zanini $A M$, et al. Saúde e cárcere: estruturação da atenção básica à saúde no sistema prisional do Rio Grande do Sul. Sist Penal Viol. 2016;8:15.

9. Brasil, Ministério da Justiça, Departamento Penitenciário (DEPEN). Relatórios analíticos: Rio Grande do Sul [Internet]. [cited 2018 Feb 23]. http://depen.gov.br/DEPEN/depen/sisdepen/infopen/ relatorios-analiticos/RS/rs

10. Superintendência dos Serviços Penitenciários (SUSEPE) [Internet]. [cited 2018 Feb 23]. http://www.susepe.rs.gov.br/

11. Fundação de Econômida e Estatística (FEE). Indicadores [Internet]. [cited 2018 Feb 23]. https://arquivofee.rs.gov.br/

12. United Nations Office on Drugs and Crime. Políticas sobre drogas e desenvolvimento sustentável é tema de nota técnica do UNODC [Internet]. 2016 [cited 2018 Feb 23]. http://www.unodc.org/ Ipo-brazil/pt/frontpage/2016/06/06-politicas-sobre-drogas-edesenvolvimento-sustentsvel-e-tema-de-nota-tecnica-do-unodc. html

13. Cipriani M. Da "Falange Gaúcha" aos "Bala nos Bala": o surgimento das "facções criminais" em Porto Alegre e sua manifestação atual. Direito Democr. 2017;17:105-30.

14. Sallin VR. As facç̃̃es e o grupo da segurança no Presídio Central de Porto Alegre: relações em um sistema social complexo [thesis]. Porto Alegre: Pontifícia Universidade Católica do Rio Grande do Sul; 2008.

15. Passos IC. A Brigada Militar no Presídio Central de Porto Alegre: o trabalho do policial militar e a mediação de conflitos [monograph]. Porto Alegre: Universidade Federal do Rio Grande do Sul; 2017.

16. Soccol KLS, Terra MG, Padoin SMM, Ribeiro DB, Siqueira DF, Canabarro JL, et al. Motivos do abuso de substâncias psicoativas por mulheres assistidas em Centro de Atenção Psicossocial. Rev Gaucha Enferm. 2018;39:1-7.

17. Wolff MP, Moraes MEB. Mulheres e tráfico de drogas: uma perspectiva de gênero. Rev Bras Cienc Crimin. 2010;18:375-95.

18. Moki MP. Representações sociais do trabalho carcerário feminino [dissertation]. São Carlos: Universidade Federal de São Carlos; 2005.

19. Guedes MA. Intervenções psicossociais no sistema carcerário feminino. Psicol Cienc Prof. 2006;26:558-69.
20. Fernandes Lopes RM, de Melo DC, Argimon IIL. Mulheres encarceradas e fatores associados a drogas e crimes. Cienc Cogn. 2010;15:121-31.

21. Dotta Panichi RM. Women in prison and mental health [dissertation]. Porto Alegre: Universidade Federal de Ciências da Saúde de Porto Alegre; 2014.

22. Bastos FI, Bertoni $N$, editors. Pesquisa nacional sobre o uso de crack: quem são os usuários de crack e/ou similares do Brasil? Quantos são nas capitais brasileiras? Rio de Janeiro: ICICT/ FIOCRUZ; 2014.

23. Instituto Nacional de Ciência e Tecnologia para Políticas Públicas de Álcool e Outras Drogas (INPAD). II Levantamento Nacional de Álcool e Drogas (LENAD) - 2012. São Paulo: UNIFESP; 2014

24. Halpern SC, Scherer JN, Roglio V, Faller S, Sordi A, Ornell F, et al. Vulnerabilidades clínicas e sociais em usuários de crack de acordo com a situação de moradia: um estudo multicêntrico de seis capitais brasileiras. Cad Saude Publica. 2017;33:e00037517.

25. Fundação Oswaldo Cruz, Instituto de Comunicação e Informação Científica e Tecnológica em Saúde. III Levantamento Nacional sobre o Uso de Drogas pela População Brasileira. Rio de Janeiro: FIOCRUZ; 2017.

26. Amorim AA, Dornelles CJV, Rudnicki D. A saúde no sistema penitenciário de Porto Alegre. Rev Inform Legis. 2013;50:285302.

27. United Nations Development Programme. Sustainable development goals [Internet]. 2016 [cited 2018 Feb 23]. https://www.undp. org/content/undp/en/home/sustainable-development-goals.html

28. Sahajian F, Lamothe P, Fabry J, Vanhems P. Consumption of psychoactive substances among 535 women entering a Lyon prison (France) between June 2004 and December 2008. Rev Epidemiol Sante Publique. 2012;60:371-81.

\section{Correspondence:}

Felipe Ornell

Centro de Pesquisa em Álcool e Drogas, Centro Colaborador em Álcool e Drogas, Hospital de Clínicas de Porto Alegre, Universidade Federal do Rio Grande do Sul

Rua Prof. Álvaro Alvim, 400

90420-020, Porto Alegre, RS - Brazil

Tel.: +55 5133596510

E-mail: felipeornell@gmail.com 